\title{
Technology adoption under seed access constraints and the economic impacts of improved pigeonpea varieties in Tanzania
}

\author{
Bekele A. Shiferaw ${ }^{\mathrm{a}, *}$, Tewodros A. Kebede ${ }^{\mathrm{b}}$, Liang $\mathrm{You}^{\mathrm{c}}$ \\ ${ }^{a}$ International Crops Research Institute for the Semi-Arid Tropics (ICRISAT), P.O. Box 39063, 00623 Nairobi, Kenya \\ ${ }^{\mathrm{b}}$ FAFO_Institute for Applied International Studies, P.O. Box 2947 Tøyen, N-0608, Oslo, Norway \\ ${ }^{\mathrm{c}}$ International Food Policy Research Institute (IFPRI), 2033 K Street, NW, Washington, DC 20006-1002, USA
}

Received 23 June 2007; received in revised form 11 March 2008; accepted 14 June 2008

\begin{abstract}
Dry-land legumes, well adapted to drought-prone areas, have largely been neglected in the past despite the good opportunities they offer for income growth and food (and nutritional) security for the poor. This study evaluated the adoption and impact of two farmer and market-preferred and disease-resistant pigeonpea varieties that were developed and promoted in semi-arid Tanzania. The new varieties were resistant to fusarium wilt, a fungal disease devastating the crop. However, farmers wanting to adopt new varieties did not adopt due to seed access constraints and underdeveloped seed delivery systems. Adoption of new varieties is therefore analyzed using an augmented double hurdle model that allows estimating variety adoption conditional on seed access thresholds accounting for the additional information on sample separation. The study identifies the crucial role of seed access (local supply), extension, education, participatory decision making, capital, and household assets in determining adoption. The social economic benefits of the technology and policies for improved seed access were further analyzed using the extended economic surplus method (DREAM model). Even under restrictive assumptions, overall discounted benefits were found to be quite attractive, indicating the need for additional efforts to scale-up the success story. Analysis of changes in research benefits from relaxing the seed access constraint showed that net gains would increase by up to $30 \%$ if farmer access to improved seeds can be assured. Smallholder farmers are the major beneficiaries along with consumers and rural net-buyers who gain from productivity-induced lower market prices.
\end{abstract}

JEL classification: $\mathrm{C} 13, \mathrm{C} 15, \mathrm{C} 34, \mathrm{C} 52, \mathrm{O} 32, \mathrm{O} 38$

Keywords: Constrained adoption; Double hurdle model; Economic surplus model; Dry-land legumes; Pigeonpea varieties; Economic impacts; Tanzania

\section{Introduction}

Grain legumes are widely grown by smallholder farmers in many semi-arid areas of the tropics. Smallholder farmers derive multiple benefits from diversification of production into grain legumes, including nutritious food, soil fertility, and cash income. Dry-land food legumes (like pigeonpea, chickpea, groundnut, etc.) help overcome severe nutritional deficiencies

\footnotetext{
*Corresponding author. Tel.: +254-20-7224554; fax: +254-20-7224001. E-mail address: b.shiferaw@ cgiar.org (B. A. Shiferaw).
}

\section{Data Appendix Available Online}

A data appendix to replicate main results is available as part of the online article from: www.blackwell-synergy.com (this link will take you to the article abstract). Please note: Blackwell Publishing is not responsible for the content or functionality of any supplementary materials supplied by the authors. Any queries (other than missing material) should be directed to the corresponding author for the article. that result from diets lacking in protein and oil. They provide protein-rich supplementary food to many poor families that could not afford costly animal-based foods. This is especially important for growing children who cannot consume sufficient quantities of staple cereals to meet their protein requirements. Higher cash incomes and better nutrition can contribute toward improving nutritional conditions for poor families and vulnerable households. In addition, legumes fix atmospheric nitrogen that benefits both the legume and subsequent crops. Soil fertility benefits are a major consideration throughout the region as cash-constrained poor farmers cannot afford costly inputs or the returns to inorganic fertilizer use on staple cereals are low or risky to encourage widespread fertilizer adoption.

Despite their potentially high economic and environmental benefits, these pro-poor crops have largely been neglected in public policy and research and development investments, which emphasized major cereals (e.g., maize) for food security (Joshi et al., 2001; Lo Monaco, 2003). Since the colonial times, food 
legumes in Eastern and Southern Africa have been largely regarded as "subsistence" or "orphan" crops and received low priority in national agricultural research although this has started to change with increased investments by international research centers (Maredia et al., 1998). ${ }^{1}$ Hence, small-scale farmers in semi-arid areas have not been able to significantly increase productivity and harness the available technological and market opportunities for grain legumes. Some of the major limitations for diversification into grain legumes include a complex set of biotic and abiotic constraints that limit productivity of traditional varieties and lack of widely adapted and market and farmer-preferred varieties. Therefore, research on food legumes adapted to dry-land areas offers new opportunities to poor farmers in drought-prone environments to escape poverty through increased incomes and better nutrition for malnourished families.

Pigeonpea (Cajanus cajan) is an important grain legume widely grown and adapted to the semi-arid regions of South Asia and Eastern and Southern Africa. The largely droughttolerant crop allows poor families protect their livelihoods and meet their food and cash income when most other crops fail in areas with erratic rainfall. Farmers in land-scarce areas can intensify land use and harvest two crops through inter-cropping with cereals (like maize and sorghum) allowing farmers to diversify risks and maximize their incomes. The biomass can be used for feeding livestock or as source of firewood, thereby reducing the burden on women and children and reducing deforestation and loss of biodiversity. Pigeonpeas are tradable crops both in local and international markets, and export demand (mainly to south Asia) often outstrips supply (Joshi et al., 2001; Lo Monaco, 2003). Smallholder farmers market a substantial portion of the annual produce to meet their cash requirements. Tanzania is one of the major growers and exporters of the crop in the region. Tanzania exports significant amounts (30-40 thousand tons/year) to India, and there is a growing processing and value-adding industry that would allow the country to export de-hulled split pea (dhal) to the Far East, Europe, and America.

However, the pigeonpea industry in Tanzania has been affected by poor productivity and limited marketed surplus produce of smallholder farmers. The poor yields are mainly due to low yielding and disease susceptible local varieties. Farmers even abandoned production of this important crop mainly due to fusarium wilt, a fungal soil-borne disease that devastates the crop. Once the field is infested with the disease, the fungus can stay in the soil for a long period of time, making it very difficult for poor farmers to control it without the use of extended rotations or expensive chemicals. The disease is pervasive in all pigeonpea growing areas in east and southern Africa and

\footnotetext{
${ }^{1}$ The green revolution in South Asia, which was inspired by self-sufficiency in staples, also targeted cereals like wheat and rice with enhanced availability of subsidized seed, fertilizer, irrigation, and market access. In many green revolution areas of India, intensive rice and wheat monocultures have also led to agro-ecosystem degradation and declining cereal-legume rotations, traditionally used for replenishing soil fertility (Pingali and Rosegrant, 2001).
}

spreads among fields through agricultural equipment and field operations (Gwata et al., 2006).

A screening program for fusarium resistance was initiated as a concerted effort between ICRISAT and Tanzanian researchers in the early 1990s. The main thrust was to identify diseaseresistant types that combine market and farmer-preferred traits. By 1997, this effort resulted in the development of 21 varieties that were successfully tested on-station, which was followed by participatory on-farm testing and evaluation of a few promising lines. Two of these fusarium-resistant improved pigeonpea (FRIP) varieties (ICEAP 00040 and 00053), which embody farmer and market-preferred traits, are becoming popular in northern Tanzania. Farmers, however, face seed-access constraints that limit the quick spread of the technology to wider areas. Using empirical data from this region where the technologies were initially tested and promoted, this study analyzes the key determinants of variety adoption and the overall economic benefits to Tanzania. Unlike many previous adoption studies, technology adoption is modeled conditional on farmer access to new seeds and takes into account the thresholds that smallholder farmers need to overcome at different stages before actual adoption takes place. This improves the consistency of the parameter estimates.

\section{Modeling constrained adoption}

\subsection{Legume seed systems in Tanzania}

Access to improved seed is an integral factor for stimulating technology uptake and increasing agricultural productivity in smallholder agriculture. The weak seed supply systems in many sub-Saharan countries of Africa have been identified as limiting factors for widespread adoption of improved varieties (Cromwell, 1996; Morris, 1998; Rohrbach and Tripp, 2001; Tripp, 2000). Despite efforts to liberalize markets for grain and seed, the commercial seed sector has been very slow to develop, especially for open-pollinated varieties of cereals and legumes where farmers can save their own seed for some years once they gain access to the new varieties. This is the case for legumes and non-hybrid cereal varieties. There are also several entry barriers and rigidities that limit the participation of the private sector in seed supply in Africa. These include poor rural infrastructure, free or subsidized seed through relief and recovery programs, requirements for variety registration, restrictions on seed imports, and at times price regulation (e.g., see Rohrbach and Tripp, 2001). In cases where seed laws are deficient or quality control systems are weak, seed traders cannot often differentiate quality seed from food grains, leading to the classic problems of asymmetric information in markets. The lack of incentives for commercial seed companies means that the public sector and informal seed systems would be required to fill the gap. But the public sector seed agencies are often characterized by high overhead costs and inefficiency while informal seed systems lack capacity to meet seed demand in the desired 
quantity and quality. These factors have jointly contributed to market failures or inefficiencies in seed systems and contributed to inadequate production and marketing of publicly developed crop varieties and their poor adoption by farmers.

In Tanzania, seed production and marketing is largely by the informal sector (i.e., about $90 \%$ of seed produced and marketed is handled by the informal sector. The informal seed systems include farmer-to-farmer seed exchange, community seed production, borrowing from relatives/neighbors, and exchanging or purchasing stored food grains recycled as seed by farmers. The formal seed system constitutes a network of private seed companies and rural input dealers or stockists selling certified seeds and parastatals (e.g., Agricultural Seed Agency) that produces and markets foundation and some certified seed. There are over 22 private seed companies registered in Tanzania, but only a few of them handle pigeonpea seed, in limited quantities, when contracted by identified buyers. Most of the seed companies deal with certified seed of hybrid maize and crops that have a relatively large seed market (e.g., sorghum, rice, vegetables, and other commercial crops). In recognition of these limitations, Tanzania has introduced a semi-formal community based seed system that combines some features of the more flexible informal systems and the regulatory framework of the formal system. This is called quality declared seed (QDS) and relies on truthfully labeled seed produced by trained farmers under the inspection of the regulatory agency and marketed within the community. This was mainly intended to meet the seed demand for crops and varieties where the private sector has limited interest. While legumes like pigeonpea are included under the QDS system, much less has been achieved so far due to lack of access to foundation seed, inadequate seed inspection service, poor awareness of available varieties, and lack of capacity for farmer training in legume seed production systems.

The informal and semi-formal seed systems in Tanzania are therefore faced with challenges of shortage of foundation seed, poor seed quality, irregular supply, lack of processing equipment, and limited market orientation. ${ }^{2}$ In the absence of stronger formal seed systems, pigeonpea farmers have often relied on farmer-to-farmer seed transfer, participation in on-farm variety selection, and supply by non-governmental organizations (NGOs). Several options have been suggested to relax the constrained supply of legume seed-increased supply of foundation seed through private-public sector alliances, marketing of small seed packs, enhancing the capacity of farmer groups to produce, and market quality declared seed. The study will model and test the effect of constrained access to seed and propose policy alternatives for stepping up the delivery of pigeonpea seed for accelerating the diffusion of new pigeonpea varieties.

\footnotetext{
${ }^{2}$ The potential annual seed demand for the country has been estimated at about 120 tons while the actual or effective demand is estimated around 30 tons. At the moment, the total annual seed supply is about 12.8 tons, with maize using about 8-10 tons. The contribution of legumes in the formal seed supply is very low particularly after the collapse of the former TANSEED Company, which used to produce some legume seed, especially beans (Lyimo, 2008).
}

\subsection{Constrained technology adoption}

Numerous econometric models have been applied to study the adoption behavior of farmers and to identify the key determinants of technology adoption. The econometric specification largely depends on the purpose of the study and the type of data available. In many cases, data are collected on whether a given technology has been adopted or not, without additional information on whether some individuals are constrained in accessing the technology. For dichotomous dependent variables, probit and logit models are commonly used. When data on the level of use of the technology is available, the censored regression model, also called the Tobit model (Maddala, 1983; Tobin, 1958) has also been commonly used for modeling adoption behavior (e.g., Adesina and Zinnah, 1993; Kristjanson et al., 2005; Shiyani et al., 2002). The key underlying assumption for a Tobit specification is that farmers with a positive desired demand have unconstrained access to the technology. In situations where seed supply systems are underdeveloped, this is often untenable as farmers wanting to plant new varieties often face seed access constraints. The Tobit specification has no mechanism to distinguish such households with a constrained positive desired demand from those with unconstrained positive demand and considers a zero amount of land under improved technology as a rational decision by the farmer not to plant any improved variety, hence yields inconsistent parameter estimates (Croppenstedt et al., 2003).

As a first stage, farmers need to develop a positive desired demand for new varieties based on their evaluation of net benefits from comparing old and new cultivars. Information is critical in facilitating this process and in creating demand for new varieties. However, in addition to information, actual adoption and planting of new cultivars depends on local availability of quality seeds and the ability of the farmer to access this input. In other cases, access to credit, or lack of suitable land, or other resources, could be an important impediment that some farmers wanting to plant new varieties need to overcome before actually growing new cultivars. In our case, access to improved seeds related to village supply was the key threshold that farmers (with positive desired demand) had to overcome. ${ }^{3}$ This is consistent with several studies in the past documenting the critical role of underdeveloped seed supply and marketing systems for farmer variety choice and technology adoption in smallholder agriculture (Cromwell, 1996; Morris, 1998; Tripp, 2000). In such a case, the Double Hurdle (DH) model (Cragg, 1971) gives consistent estimates. The DH model has been used in modeling constrained adoption and intensity of use of new technologies mainly because it accounts for the existence of a significant number of farmers with positive desired demand for modern inputs but are too constrained to adopt them (Coady, 1995; Croppenstedt et al., 2003). The DH model has also been

\footnotetext{
${ }^{3}$ All the seed constrained farmers in our sample indicated that the major limiting factor was lack of village supply. This may reflect the small seed requirements for pigeonpea $(10-15 \mathrm{~kg} / \mathrm{ha})$, which makes it possible for most farmers to afford buying seeds, but only if supply side constraints are addressed.
} 
applied in off-farm labor supply studies where workers face various entry barriers (e.g., Matshe and Young, 2004; Woldehanna et al., 2000).

In this study, some farmers reported problems in accessing improved seeds as one of the major constraints for uptake of new varieties. Among the 240 households surveyed, about $22 \%$ reported lack of access to improved seeds due to lack of village supply as the major limiting factor for non-adoption. About $34 \%$ of the respondents had access to improved seed and planted these varieties at least for two seasons (hence considered as early adopters). About $44 \%$ of the farmers did not, however, adopt new varieties at this early stage of the diffusion process not because of seed access constraints but due to incomplete information and uncertainties on the profitability of new FRIP varieties, indicating that these farmers are likely to adopt in the future as they gain more experience in growing new cultivars. The availability of this information from the survey data creates a unique opportunity to separate the sample into three groups. Using this sample separation, we augment the DH model to incorporate this additional information and obtain more efficient estimates.

The unobserved desired demand for improved seed for farmer $i$ can be modeled as:

$Y_{i}^{*}=\beta^{\prime} X_{i}+u_{i}$

where $X$ is a vector of variables that determine the demand function, $\beta$ is parameter vector, and $u$ is normal random variable with mean 0 and variance $\sigma_{u}^{2}$. Similarly, the latent variable underlying an individual farmer's access to improved seed can be modeled as:

$A_{i}^{*}=\alpha^{\prime} Z_{i}+e_{i}$

where $Z$ is a vector of variables that affect access, $\alpha$ is the parameter vector, and $e$ is random variable distributed as normal with mean 0 and variance 1 . The observed improved seed demand $\left(Y_{i}\right)$ is characterized by the interaction of model (1) and (2). A positive use of improved seed is observed if two thresholds are passed in the decision making process: the farmer has passed the positive demand threshold $\left(Y_{i}^{*}>0\right)$ and has access to improved seed $\left(A_{i}^{*}>0\right)$. This comprises the first group in the sample. The second group in the sample consists of farmers who do not want improved seed $\left(Y_{i}^{*}<0\right)$ whether they have access to improved seed or not $\left(A_{i}^{*}>0\right.$ or $\left.A_{i}^{*} \leq 0\right)$. The third group in the sample constitutes farmers who want improved seed $\left(Y_{i}^{*}>0\right)$ but cannot get it because they do not have access to improved seed $\left(A_{i}^{*} \leq 0\right)$. Several studies (Jones, 1992; Kimhi, 1999; Moffatt, 2005) have applied variants of the DH model where the independence of the two equations (1 and 2 ) is tested and the independence assumption could not be rejected. Smith (2003) shows that assuming dependency between the two equations is not a worthwhile exercise as there is little statistical information available to support dependency in a DH framework. Accordingly, we assume that the access and demand equations are independent and the log likelihood function for the sample-separated data can be expressed as:

$$
\begin{aligned}
\ln L= & \sum_{G 1=1} \ln \left[\Phi\left(\alpha^{\prime} Z_{i}\right) \times\left(1 / \sigma_{u}\right) \times \phi\left(\left(Y_{i}-\beta^{\prime} X_{i}\right) / \sigma_{u}\right)\right] \\
& +\sum_{G 2=1} \ln \left[1-\Phi\left(\beta^{\prime} X_{i} / \sigma_{u}\right)\right] \\
& +\sum_{G 3=1} \ln \left[\Phi\left(\beta^{\prime} X_{i} / \sigma_{u}\right) \times\left(1-\Phi\left(\alpha^{\prime} Z_{i}\right)\right)\right]
\end{aligned}
$$

where $\phi$ and $\Phi$ are the probability density and cumulative distribution function of the standard normal variable, respectively; G1, G2, and G3 are indicator functions whether a given observation belongs to group one, two, or three, respectively, as described earlier.

Equation (3) can be estimated using maximum likelihood (ML) techniques resulting in consistent estimates of the parameters. The marginal effect of a given variable $x_{j}$ on quantity demanded can be given as:

$$
\begin{gathered}
\frac{\partial E(Y \mid X, Y>0)}{\partial x_{j}}=\beta_{j}\left\{1-\lambda\left(\beta^{\prime} X / \sigma_{u}\right)\left[\beta^{\prime} X / \sigma_{u}\right.\right. \\
\left.\left.+\lambda\left(\beta^{\prime} X / \sigma_{u}\right)\right]\right\}
\end{gathered}
$$

where $E(Y \mid X, Y>0)=\beta^{\prime} X+\sigma \times \lambda\left(\beta^{\prime} X / . \sigma\right)$ and $\lambda(k)=$ $\phi(k) / \Phi(k)$ for any $k$. This can be evaluated at the maximum likelihood estimates $\hat{\beta}$ and the relevant sample means. The marginal effects for improved seed access probability can be given by $\alpha_{j} \phi\left(\alpha^{\prime} X\right)$ evaluated at the ML estimates and at sample means of the regressors. The probability of adoption can be obtained as the product of probabilities of improved seed access, $\Phi\left(\alpha^{\prime} Z_{i}\right)$ and probabilities of participation $\Phi\left(\beta^{\prime} X_{i} / . \sigma_{u}\right)$ evaluated at the ML estimates and at the relevant sample means.

\subsection{Evaluating economic impacts}

The main objective of the project, which developed the FRIP varieties, was to maximize the research benefits to smallholder farmers from increased productivity and reduced risk of crop loss from controlling the devastating wilt disease. This study is interested in investigating the extent to which these economic benefits can be realized, and to what extent the gains can be increased from relaxing farmer access to improved seeds. Therefore, a complimentary analysis of the wider potential net benefits of the technology and the associated gains from enhancing farmer access to new varieties was undertaken using the economic surplus approach. However, tracking the impacts to producers and consumers of new varieties in a given setting often requires careful analyses of the changes that can be directly attributed to the intervention itself (Baker, 2000). In the case of interventions that also generate non-tangible and non-marketed environmental benefits and ecosystem services, the overlapping problems of measurement, valuation, and attribution pose serious methodological limitations for a comprehensive impact 
evaluation (Shiferaw et al., 2004). Although diversification and intensification of food legumes is likely to generate such multiple social and environmental benefits, this study has focused mainly on the measurable economic outcomes and impacts of variety adoption.

The economic returns to investments in developing the wiltresistant pigeonpea varieties were estimated using the dynamic research evaluation for management (DREAM) model (Alston et al., 1995; Wood et al., 2001). The DREAM approach is based on the economic surplus method where research-induced supply triggers a process of market-clearing adjustments in one or multiple markets that would affect the flow of final benefits to producers and consumers (Alston et al., 1995). Linear equations are used to represent supply and demand in each region with market clearing enforced by a set of quantity identities and price identities. It is a single-commodity model without explicit representation of cross-commodity substitution effects in production and consumption, but these aspects are represented implicitly by the elasticities of supply and demand for the commodity being modeled. Basic region-specific data on quantity produced and consumed, producer and consumer prices, elasticities of supply and demand, and exogenous growth in supply and demand are needed to capture pre-adoption economic conditions. DREAM has been developed into a computer software package (Wood et al., 2001). It has a menu-driven, user-friendly interface that hides the complex computation to allow users to focus on methodology, data collection, and policy interpretation. ${ }^{4}$ The empirical formulation of the model and the necessary parameters will be discussed further in the next section.

\section{Data and model specification}

Data for this study come from a stratified random sample of 240 farm households in Babati district of northern Tanzania, the largest producer of pigeonpea in this region. The district accounts for about a third of the total area, production, and export of pigeonpea in Tanzania. Smallholder agriculture is the main economic activity that underpins livelihoods in the district. Because of the relative geographical isolation and poor connectivity with the major urban markets, the overall level of market access in the district is low. The district is connected with the city of Arusha (about $650 \mathrm{~km}$ from Dar es Salaam) through a 164-km road, about $90 \mathrm{~km}$ of which is laid with tarmac. The existence of hydroelectric power and telecom facilities opens opportunities for further development of pigeon-pea traders and agro-enterprises.

The study was conducted in the three administrative wards of Babati district (Babati, Singe, and Bonga) where improved varieties have initially started to spread. Two villages were randomly selected from each of the three wards from which a random sample of 40 households was taken for a detailed

\footnotetext{
${ }^{4}$ The latest version of the DREAM model can be downloaded from the IFPRI website: http://www.ifpri.org/themes/grp01/dream/download.htm
}

household survey from each of the selected villages. Using a special adoption and impact monitoring instrument, detailed input and output data for the 2003 production season, covering household characteristics, assets, production costs and returns, variety choice, and market participation were generated from both adopting and non-adopting households in each village. In addition, data were also obtained for the 2004 season on variety choice and area planted of different crops, although the full costs and returns were not known as the pigeonpea crop was not harvested at the time of the survey. The survey was administered in June to August 2004 using trained enumerators who stayed in the villages and spoke local languages.

\subsection{Empirical adoption model}

The augmented DH model is specified using variables that affect the choice of cultivars and have a positive desired demand for improved varieties in the first stage and access to improved seeds in the second stage to make adoption possible. For farmers with positive desired demand, the overall demand for improved varieties - defined as area planted to FRIP varieties - is then determined conditional on the ability to access new seeds. The choice of variables for the empirical model, however, needs to be informed by theoretical and empirical findings in similar studies. Smallholder farmers in many rural areas are semi-subsistence producers and consumers partially integrated into imperfect rural markets. Factor markets for labor, land, traction power, and credit in rural areas of developing countries are often imperfect and/or even missing in some cases (Holden et al., 2001; Pender and Kerr, 1998). When rural input and output markets are imperfect, production and technology adoption decisions are influenced by the level of poverty and asset ownership of the farmer (de Janvry et al., 1991; Singh et al., 1986). This implies that assuming imperfections in labor, credit, land, and other input markets, household characteristics and assets would be important factors in technology choice decisions. Besides, other policy variables, like perceptions about the technology attributes, access to information, and local availability of improved seeds, are critical factors in technology choice. About two-thirds of the non-seed supply constrained non-adopters who were aware of the available FRIP varieties indicated insufficient information about agronomic and management practices as a major constraint to adoption. Hence, access to relevant information is an important factor in determining the demand for and adoption of improved varieties. Various proxies are used to capture this effect in the analysis of the key determinants of seed access and the intensity of technology adoption conditional on accessing improved seeds. Information is hypothesized to determine both access to seed and the intensity of adoption. In order to identify the barriers to and enabling conditions for variety adoption, several such additional variables are included in the DH model. We first identify the variables that condition the probability of access to quality seeds of improved varieties. 
Ability to access improved seeds may be influenced by household characteristics (e.g., gender), endowment of some key household wealth assets (land, livestock, transport equipment, etc.), ability to access and digest information, and supply side factors such as history of participation in farmer-to-farmer (FTF) seed exchange and in participatory variety selection (PVS). While radio and TV may help in accessing information from formal seed systems, experience in FTF seed exchange will be critical for harnessing informal seed systems. The wealth effects were captured through two assets (land and livestock); information effects through education, participation in PVS, and ownership of radio, TV, telephones, etc.; saved seed effects through initial stock of seed from previous season; the effect of transport infrastructure and transaction costs through ownership of bicycles and ox-drawn carts; and experience in informal seed systems through past involvement in FTF seed exchange. ${ }^{5}$ All these variables were expected to enhance the probability of access for improved seeds for a given household. The effect of household characteristics was captured through the gender factor to test whether women farmers (17.5\% of the sample farmers were female) have special access constraints. In addition, we included ward/village factors to test whether access constraints vary by geographical region.

For those farmers with positive desired demand, the level of adoption is hypothesized to depend positively on participatory decision-making in variety choice and planting decisions; farmer skills (proxied through education); whether farming is the main occupation; working capital proxied through cash income from previous year; access to information proxied through knowledge about improved varieties and participation in PVS; share of maize (often intercropped with pigeonpeas); total available labor proxied through male and female workforce of the family; and assets owned (farm size, livestock, and non-livestock assets). We also included household characteristics (gender and age) to test whether these factors had any measurable effects on the level of adoption of improved varieties. The descriptive statistics for the variables included in the augmented DH model are given in Table 1.

Diagnostic tests were performed to identify any potential misspecification problems that may exist in the estimated model. Multicollinearity is a usual suspect in any regression context. The presence of such a problem would lead to estimates that are unstable and have high standard error resulting in the insignificance of most or all of the explanatory variables. In order to test this potential problem, multicollinearity diagnostic tests based on variance inflation factor (VIF) were performed. The test showed that the largest VIF resulting from the principal component analysis performed was 1.88 , which is well below the

\footnotetext{
${ }^{5}$ As in many rural settings, credit markets in the study area are highly imperfect. It is hence hypothesized that household assets and working capital would have a positive effect on adoption. Since available information on borrowing alone does not reflect household liquidity constraints and planting pigeonpea requires small quantities of seed, working capital and household assets were used as proxies to capture any effect of the credit constraint on effective seed demand.
}

maximum value of 10 that is used as a rule of thumb to characterize the presence of multicollinearity. Hence, multicollinearity is not considered a problem in our analyses. Moreover, in addition to the augmented DH model, we also estimated the Tobit model in order to test the extent of thresholds that some farmers face in accessing seeds of improved varieties. The Tobit model does not take into account threshold of seed access and hence has a different distribution than that of our augmented DH model. Vuong (1989) has proposed a test statistic suitable for comparing models of such type. Let $f_{j}\left(y_{i} \mid X_{i}\right)$ denote the predicted probability that the random variable $Y$ equals $y_{i}$ under the assumption that the distribution is $f_{j}\left(y_{i} \mid X_{i}\right)$, for $j=1$ for the DH model and $j=2$ for the Tobit model. Also, let

$m_{i}=\log \left(\frac{f_{1}\left(y_{i} \mid X_{i}\right)}{f_{2}\left(y_{i} \mid X_{i}\right)}\right)$.

Voung's statistics for testing the hypothesis of DH model versus Tobit model is

$$
v=\frac{\sqrt{n}\left[\frac{1}{n} \sum_{i=1}^{n} m_{i}\right]}{\sqrt{\frac{1}{n} \sum_{i=1}^{n}\left(m_{i}-\bar{m}\right)^{2}}} .
$$

Vuong shows that $v$ has limiting standard normal distribution. If $|v|$ is less than two, then the test does not favor one model over the other. Large values favor the DH model whereas small negative values favor the Tobit model. In our analysis, Vuong's statistic appears to favor the DH model for adequately describing the data; the value is 27.39. One should also note that the DH adoption model is estimated as a static cross-sectional model, but adoption or technology diffusion is actually a dynamic process. If the same model had been estimated at a later point in time, the results might differ from what is reported here at early stages of technology adoption pathway. Whereas the major structural constraints limiting access to seed and FRIP varieties remain, the overall level of adoption and awareness of new varieties is likely to improve over time. The recent high food price trends can also be expected to stimulate variety adoption.

\subsection{Calibration of the economic surplus model}

As discussed earlier, the DREAM model is used for estimating the economic surplus resulting from the pigeonpea research investments. The direct economic impact of the new varieties was evaluated under the assumption of three horizontal markets: Babati district, rest of Tanzania (ROT), and the rest of the world (ROW). This implied an open economy that would require a global market clearing condition whereby the total production across the three regions must equal the total consumption. The price transmission elasticity is used to allow some degree of price diffusion between the three regions. DREAM 
Table 1

Descriptive statistics of regression variables by seed access constraint

\begin{tabular}{|c|c|c|c|c|c|c|}
\hline \multirow[t]{2}{*}{ Variables } & \multicolumn{2}{|c|}{$\begin{array}{l}\text { Have access to seed } \\
\text { and adopted }(n=81)\end{array}$} & \multicolumn{2}{|c|}{$\begin{array}{l}\text { Access not a major constraint } \\
\text { but did not adopt }(n=105)\end{array}$} & \multicolumn{2}{|c|}{$\begin{array}{l}\text { Have no access and } \\
\text { did not adopt }(n=54)\end{array}$} \\
\hline & Mean & Std. Dev. & Mean & Std. Dev. & Mean & Std. Dev. \\
\hline Total pigeonpea area (acres) & 3.52 & 3.34 & 2.48 & 2.08 & 2.40 & 2.76 \\
\hline Improved variety area (acres) & 2.60 & 2.12 & 0 & 0 & 0 & 0 \\
\hline Sex of head $($ male $=1)$ & 0.88 & 0.33 & 0.78 & 0.42 & 0.83 & 0.38 \\
\hline Women participate in decisions (yes $=1$ ) & 0.42 & 0.50 & 0.30 & 0.46 & 0.39 & 0.49 \\
\hline Age of head (years) & 47.10 & 12.81 & 49.31 & 15.53 & 47.04 & 16.22 \\
\hline Farming main occupation (yes $=1$ ) & 0.99 & 0.11 & 0.99 & 0.10 & 0.96 & 0.19 \\
\hline Head education 1 to 4 years & 0.17 & 0.38 & 0.21 & 0.41 & 0.17 & 0.38 \\
\hline Head education 5 to 8 years & 0.59 & 0.49 & 0.49 & 0.50 & 0.50 & 0.50 \\
\hline Head education greater than 8 years & 0.05 & 0.22 & 0.03 & 0.17 & 0.06 & 0.23 \\
\hline Working capital $(1,000 \mathrm{Tsh})$ & 468.55 & 481.05 & 225.28 & 278.37 & 257.20 & 319.65 \\
\hline Participated in PVS & 0.51 & 0.50 & 0.11 & 0.32 & 0.19 & 0.39 \\
\hline Number of improved varieties known & 1.83 & 0.95 & 0.32 & 0.74 & 1.74 & 0.78 \\
\hline Area share of maize & 0.74 & 0.28 & 0.86 & 0.24 & 0.80 & 0.26 \\
\hline Total family workforce & 2.50 & 1.27 & 2.59 & 1.49 & 2.21 & 1.06 \\
\hline Farmsize per capita & 0.91 & 1.49 & 0.52 & 0.39 & 0.54 & 0.36 \\
\hline Oxen per capita & 0.29 & 0.63 & 0.16 & 0.32 & 0.30 & 0.44 \\
\hline Non-oxen livestock wealth per capita (1,000 Tsh) & 50.45 & 52.26 & 35.46 & 43.95 & 47.49 & 62.39 \\
\hline Non-livestock wealth per capita (1,000 Tsh) & 16.32 & 22.26 & 87.53 & 11.74 & 14.86 & 17.78 \\
\hline Seed saved from previous season & 3.96 & 6.28 & 0.51 & 2.37 & 0.09 & 0.68 \\
\hline Experience in FTF seed exchange (yes $=1)$ & 0.68 & 0.47 & 0.24 & 0.43 & 0.26 & 0.44 \\
\hline Owns a cart for transport (yes $=1$ ) & 0.28 & 0.45 & 0.10 & 0.29 & 0.11 & 0.32 \\
\hline Owns bicycle & 0.64 & 0.48 & 0.49 & 0.50 & 0.69 & 0.47 \\
\hline Owns TV or radio or phone & 0.73 & 0.45 & 0.53 & 0.50 & 0.61 & 0.49 \\
\hline Singe ward & 0.52 & 0.50 & 0.22 & 0.42 & 0.28 & 0.45 \\
\hline Bonga ward & 0.31 & 0.46 & 0.36 & 0.48 & 0.31 & 0.47 \\
\hline
\end{tabular}

allows technology spillovers from one region to the other. This is specified in the spillover matrix and a conservative coefficient of 0.5 is used, which assumes that $50 \%$ of the cost-saving or productivity benefits realized in Babati district would also be achieved in other pigeonpea growing areas of the country. This is mainly because we assumed that the new varieties may not achieve the full potential attained in Babati district where they were initially evaluated and the strong partnerships between the different $R \& D$ institutions observed in the district may not be replicated in other areas. The baseline market conditions used in the model are given in Table 2. These baseline values were compiled from national production statistics, review of literature, and the best available information on DREAM model parameters at IFPRI and other sources (e.g., Alston et al., 1995; Oehmke and Crawford, 2002). Pigeonpea supply elasticity in Tanzania was not available. Following Alston et al. (1995), we assume a supply elasticity of one. Using Nweke et al.'s (2000) estimated elasticities for pulses in sub-Saharan Africa, the demand elasticity for pigeonpea was taken as -0.6 . The other technology specific parameters used in calibrating the model were estimated based on our household survey results and/or estimated based on observed patterns of research and technology adoption in Tanzania.

In order to calibrate the model to conditions that reflect the research process and broad patterns observed in the variety adoption pathway, we included the following additional specifications: a research lag of 9 years, an adoption lag of 7 years (following a logistic adoption pattern), a maximum adoption level of $40 \%$ sustained over a period of 5 years, followed by 9 years for farmers to abandon the technology and shift to other varieties. The costs for research, adaptation, and extension of improved varieties were included based on actual and estimated expenditures for a planning horizon of 30 years. The estimated costs of both national and international scientists and staff and other operating costs in developing and locally adapting the FRIP varieties were included. These data were collected from project documents and from discussions with local research and extension partners in Tanzania.

The wider economic net benefits are computed using average realized yield gains at the farm level estimated, based on our household survey data. The sample farmers estimated a yield loss of about $55 \%$ due to wilt infestation when they grow local varieties. The corresponding estimated loss was about $5 \%$ when they grow improved resistant varieties. The average estimated yield gain from growing new varieties was about $67 \%$ (Table 3 ). Since there is a lack of information on the extent of fusarium infestation or the probability of infestation of uninfected fields for the country at large, we assumed similar levels of infestation as in Babati district for the rest of Tanzania. The available information also suggested that Babati district is not a special case when it comes to the fusarium problem in the region (Gwata et al., 2006). In order to show the degree of variation in the estimated economic surplus due to changes in key parameter values, a sensitivity analysis was carried out in relation to the 
Table 2

Initial market conditions used in the DREAM model

\begin{tabular}{|c|c|c|c|c|c|c|c|c|c|c|}
\hline \multirow[t]{3}{*}{ Region } & \multicolumn{2}{|c|}{ Quantity $(1,000 \mathrm{t})$} & \multirow{3}{*}{$\begin{array}{l}\text { Price } \\
\text { US }(\% / t)\end{array}$} & \multicolumn{2}{|c|}{ Elasticity } & \multirow{3}{*}{$\begin{array}{l}\text { Price trans. } \\
\text { elast. }\end{array}$} & \multirow{2}{*}{\multicolumn{2}{|c|}{$\begin{array}{l}\text { Exogenous } \\
\text { growth }(\% / y r)\end{array}$}} & \multirow{2}{*}{\multicolumn{2}{|c|}{$\begin{array}{l}\text { Growth of Taxes/ } \\
\text { subsidy }(\% / y r)\end{array}$}} \\
\hline & \multirow{2}{*}{ Production } & \multirow{2}{*}{ Consumption } & & \multirow{2}{*}{ Supply } & \multirow{2}{*}{ Demand } & & & & & \\
\hline & & & & & & & Supply & Demand & Supply & Demand \\
\hline Babati & 14.1 & 1.6 & 197 & 1.0 & 0.6 & 0.2 & 0.5 & 0.3 & 0.5 & 0.1 \\
\hline Rest of Tanzania & 29.9 & 14.7 & 197 & 1.0 & 0.6 & 0.2 & 0.5 & 0.25 & 0.5 & 0.1 \\
\hline Rest of the world & $2,869.8$ & $2,897.5$ & 325 & 1.0 & 0.6 & 0.25 & 0.25 & 0.2 & 0 & 0 \\
\hline
\end{tabular}

Source: Compiled from different sources including FAOSTAT and national statistics.

Table 3

Comparative farm-level economic benefits from pigeonpea varieties (2003)

\begin{tabular}{|c|c|c|c|c|}
\hline Variable & $\begin{array}{l}\text { Local varieties } \\
(N=195)\end{array}$ & $\begin{array}{l}\text { Improved varieties } \\
(N=59)\end{array}$ & Net gain & $\begin{array}{l}\text { Change } \\
(\%)\end{array}$ \\
\hline Yield (kg/ha) & 425 & 709 & 284 & 67 \\
\hline $\begin{array}{l}\text { Gross value of } \\
\text { production } \\
(\mathrm{Tsh} / \mathrm{ha})\end{array}$ & 83,335 & 137,607 & 54,272 & 65 \\
\hline $\begin{array}{l}\text { Variable costs } \\
\text { (Tsh/ha) }\end{array}$ & 21,439 & 26,420 & 4,981 & 23 \\
\hline $\begin{array}{l}\text { Variable costs } \\
\text { per kg }\end{array}$ & 50 & 37 & -13 & -26 \\
\hline $\begin{array}{c}\text { Net income } \\
\text { (Tsh/ha) }\end{array}$ & 61,897 & 111,186 & 49,289 & 80 \\
\hline $\begin{array}{l}\text { Net returns per } \\
\text { unit of } \\
\text { investment }\end{array}$ & 2.89 & 4.21 & 1.32 & 46 \\
\hline
\end{tabular}

Note: The exchange rate during 2004 was about 1 US $\$=875$ Tsh.

key model parameters (supply and demand elasticities, yield gain, and spillover coefficient). These new estimated values are compared with the baseline results.

In addition, as indicated earlier, we create a link between the econometric results on adoption constraints and the economic surplus model by analyzing the potential economic surplus that may result from relaxing the seed access constraint. Tackling the seed access constraint would make it possible for those with positive demand to actually plant the new varieties and encourage others to try new cultivars. The estimated probabilities of seed access and adoption rates from the econometric analysis feed into the economic surplus model to estimate the gains from relaxing the seed access constraint. This captures the effect of enhanced seed availability, which increases the adoption ceiling as well as reduces the adoption lag, i.e., the time required for farmers to adopt new varieties once the technology is available. The approach followed in linking the econometric and economic surplus analysis is similar to Moyo et al. (2007), but lack of large-scale data on poverty profiles in the pigeonpea growing areas in Tanzania prevents us from distributing the surplus to assess the potential changes in poverty indices.

\section{Results and discussion}

In the following sections, we present the analytical results on the economics of new varieties, the process and factors determining access to and the intensity of adoption of improved varieties, including the effect of selected policy relevant variables in determining the probability and intensity of adoption, and the potential economic impacts of the new varieties in Tanzania.

\subsection{Economics of new varieties}

All the surveyed farmers grew pigeonpea in 2003-2004 and about $35 \%$ planted at least one of the improved varieties, an increase from $25 \%$ during the previous season. About $26 \%$ of the farmers grew only improved varieties, $9 \%$ grew both improved and local varieties, and $65 \%$ grew only local varieties. The ratio of partial adoption (share of improved varieties out of the total pigeonpea area) increased from 24\% in 2002-2003 to $32 \%$ during 2003-2004. The two varieties (ICEAP 00040 and 00053), which combine resistance to fusarium wilt and embody the market-preferred traits (large and cream colored seeds), were most preferred by farmers. Recent visits to the region have shown that the level of diffusion has continued to increase within the district and beyond to other parts of Tanzania through formal and informal seed networks. As we show below, this process is facilitated by improved availability of new seeds, farmer-tofarmer technology exchange, and better market linkages created through enhanced private sector participation in seed and output marketing.

The majority of the farmers $(85 \%)$ reported that they had incidence of fusarium wilt in their fields. However, very few of them $(6 \%)$ applied some control measures, mainly crop rotations. Respondents who adopted new varieties reported that local varieties were more susceptible to the wilt disease than the improved varieties. While about $96 \%$ of local variety growers reported infestation by fusarium wilt in some of their fields, only about $13 \%-15 \%$ of growers of improved varieties reported wilt infestation of the crop.

Average yields varied significantly across villages and also between the improved and local varieties. Improved varieties had superior yields over the local landraces. The average yield from the local susceptible varieties was about $425 \mathrm{~kg} / \mathrm{ha}$ which compares with $709 \mathrm{~kg} / \mathrm{ha}$ for improved varieties (Table 3). This represents an average yield gain of $67 \%$ in switching to improved varieties. As the agronomic yield difference between the local and traditional varieties is minimal on disease free 
plots, much of this gain is realized from the reduced productivity loss when wilt resistant cultivars are grown on infested fields. Whereas total variable costs of production are higher, because of higher average yields, average costs of production per unit of output are $26 \%$ lower for improved varieties. On average, farmers adopting new varieties have an $80 \%$ higher net income per ha from pigeonpea production than non-adopting farmers, showing the extent of additional benefits that farmers may derive if they switch to the disease resistant new varieties. Information about the potential of new FRIP varieties and access to such seeds are critical factors in realizing these benefits.

\subsection{Determinants of seed access}

The jointly estimated DH model results for seed access are given in the bottom half of Table 4. Most of the variables in the model have hypothesized signs. Farmer access to improved seeds was significantly determined by several of the model variables. Among the information variables, participation in on-farm variety testing (PVS) was significant. Neither the education variables nor ownership of radio and telephones had any significant effect on accessing improved seed. This may actually show that information per se was not the major limiting factor determining the farmer's ability to get hold of improved seeds. The PVS effect may also reflect any small amounts of seed that may have been received during the on-farm trials, but many farmers took part in demonstrations and field days arranged to inform villagers about the performance of different pigeonpea cultivars on farmers' fields. We also found no significant effect of gender in conditioning seed access (controlling for other factors) implying that men and women farmers are likely to have similar opportunities in accessing improved seeds. The other important factors included participation in informal seed networks (FTF) and the initial amount of seed received in the past, indicating the effect of saving and recycling of seed

Table 4

Double hurdle and Tobit regression estimates

\begin{tabular}{|c|c|c|c|}
\hline Variables & $\begin{array}{l}\text { Double hurdle coef } \\
\text { (standard errors) }\end{array}$ & $\begin{array}{l}\text { Marginal } \\
\text { effect }\end{array}$ & $\begin{array}{l}\text { Tobit model coef. } \\
\text { (standard errors) }\end{array}$ \\
\hline \multicolumn{4}{|l|}{ Area planted with improved varieties } \\
\hline Sex of head $($ male $=1)$ & $0.402(.51)$ & 0.019 & $0.526(0.72)$ \\
\hline Women participate in decisions (yes $=1$ ) & $0.602(0.37)^{*}$ & 0.044 & $0.506(0.49)$ \\
\hline Age of head (years) & $-0.004(0.01)$ & -0.002 & $0.0001(0.02)$ \\
\hline Farming main occupation & $-0.124(1.23)$ & 0.002 & $1.578(1.83)$ \\
\hline Head education 1 to 4 years & $0.030(0.42)$ & 0.0001 & $0.158(0.58)$ \\
\hline Head education $>8$ years & $1.644(0.84)^{* *}$ & 0.367 & $0.196(1.11)$ \\
\hline Working capital (1,000 Tsh) & $0.001(0.0005)^{*}$ & 0.0003 & $0.002(0.001)^{* * *}$ \\
\hline Participated in PVS & $0.069(0.40)$ & 0.001 & $1.335(0.54)^{* *}$ \\
\hline Known improved varieties & $1.282(0.18)^{* * *}$ & 0.533 & $1.012(0.23)^{* * *}$ \\
\hline Area share of maize & $0.115(0.63)$ & 0.048 & $-0.137(0.85)$ \\
\hline Total family workforce & $-0.040(0.13)$ & -0.017 & $0.262(0.18)$ \\
\hline Farm size per capita & $0.694(0.19)^{* * *}$ & 0.289 & $1.196(0.25)^{* * *}$ \\
\hline Oxen per capita & $-0.546(0.44)$ & -0.227 & $-1.349(0.63)^{* *}$ \\
\hline Per capita non-oxen livestock wealth & $0.006(0.004)^{*}$ & 0.003 & $0.004(0.004)$ \\
\hline Per capita non-livestock wealth & $0.010(0.012)$ & 0.004 & $0.002(0.015)$ \\
\hline Constant & $-2.335(1.65)$ & -0.972 & $-6.788(2.49)^{* * *}$ \\
\hline \multicolumn{4}{|l|}{ Seed access } \\
\hline Sex of head $($ male $=1)$ & $0.109(0.48)$ & 0.039 & \\
\hline Head education 1 to 4 years & $0.255(0.48)$ & 0.087 & \\
\hline Head education 5 to 8 years & $-0.100(0.41)$ & -0.036 & \\
\hline Head education $>8$ years & $-0.047(0.74)$ & -0.017 & \\
\hline Participated in PVS & $0.613(0.34)^{*}$ & 0.199 & \\
\hline Seed from previous season & $0.474(0.17)^{* * *}$ & 0.169 & \\
\hline Experience in FTF seed exchange (yes $=1$ ) & $1.103(0.31)^{* * *}$ & 0.356 & \\
\hline Owns a cart for transport & $0.932(0.44)^{* *}$ & 0.268 & \\
\hline Owns bicycle & $-0.448(0.39)$ & -0.155 & \\
\hline Owns TV or radio or phone & $0.478(0.37)$ & 0.173 & \\
\hline Singe ward & $0.828(0.38)^{* *}$ & 0.268 & \\
\hline Bonga ward & $0.535(0.40)$ & 0.180 & \\
\hline Farmsize per capita & $0.269(0.25)$ & 0.096 & \\
\hline Per capita non-oxen livestock wealth & $-0.002(0.003)$ & -0.001 & \\
\hline Constant & $-1.682(0.57)^{* * *}$ & -0.598 & \\
\hline Log likelihood & \multicolumn{2}{|c|}{-304.858} & -259.584 \\
\hline Wald chi2(15), LR chi2(15) & \multicolumn{2}{|c|}{140.92} & 100.31 \\
\hline Prob $>$ chi 2 & \multicolumn{2}{|c|}{0.0000} & 0.0000 \\
\hline
\end{tabular}

${ }^{*},{ }^{* *},{ }^{* * *}$ indicate significance at $10 \%, 5 \%$, and $1 \%$ level, respectively. 
regularly practiced by African farmers. Access was also positively affected by ownership of some transport assets (oxendrawn carts), which may have facilitated accessing seed from distant sources (e.g., input agro-dealers based in Babati town). The other asset variables (land and livestock) were not found to influence the probability of accessing seed, but we found significant differences among the villages (wards) showing that some villages may have been targeted more than others through the research and extension phases. The likelihood of accessing improved seeds was highest in Singe ward.

\subsection{Determinants of variety adoption}

The estimated parameters for the DH and Tobit models on the demand for improved varieties are shown in Table 4 (upper half). Based on the Vuong model comparison test we carried out in Section 3.1, the augmented DH model performs better than the Tobit model. This confirms the relative superiority of the DH specification for this data set and indicates that adoption of improved varieties needs to be estimated conditional on the seed access threshold. Whereas the relative magnitude and significance of most of the variables is comparable, the discussion of results will henceforth focus on the DH model. Six variables were found to have significant effects in explaining the demand for improved varieties, measured in term of area planted under FRIP cultivars. These included participatory decision-making, education, working capital, knowledge about new varieties, and per capita assets (farm size and livestock wealth). Conditional on seed access, all these variables had a positive effect on demand (area planted) for improved varieties. These results are generally in line with similar variety and input adoption studies in Africa (Croppenstedt et al., 2003; Kaliba et al., 2000; Kristjanson et al., 2005; Nkonya et al., 1997). Household attributes indexing gender, age, and main occupation were not significant. Adoption of improved varieties seems to be positively correlated with the level of household education-households with the highest level of education (greater than eight years) had higher levels of demand for improved cultivars. The positive effect of education and farmer technology awareness vari- ables (e.g., new varieties planted or known) is consistent with Nkonya et al. (1997) and Kaliba et al. (2000) for maize varieties; Kristjanson et al. (2005) for cowpea varieties; and Croppenstedt et al. (2003) for fertilizer adoption. The participation of women in variety choice and planting decisions had a significant $(P<0.1)$ positive effect on adoption of improved varieties. This seems to be partly because women give higher weights for pigeonpeas - vital for family nutrition and as source of scarce cash. Although assets do not seem to affect seed access, the demand for improved varieties conditional on access is generally positively influenced by asset levels-both in terms of working capital, farm size, and livestock wealth. This shows that better off farmers are generally better able to expand the area under improved varieties although asset ownership (other than carts for transport) did not influence access to improved seeds. The positive effect of working capital indicates that despite the low seed requirements, liquidity is still important in determining the intensity of adoption. The positive effect of livestock is consistent with the findings of Kristjanson et al. (2005) for cowpeas in Nigeria. This effect might be transmitted through feed demand that stimulates uptake of multipurpose crop varieties or through its non-stochastic wealth effect that helps to spread or buffer the risks faced by farmers. While the demand for some inputs like fertilizer (which has higher rates of factor substitution with land) may decrease with land availability (Croppenstedt et al., 2003), farm size in our case seems to stimulate the overall demand for improved varieties.

The effect of some selected variables on the probability of seed access, demand for improved varieties, and adoption are given in Table 5. This is shown for a combination of farm size and participation in PVS (for seed access) and participation of women in variety choice and planting decisions (for positive desired demand of new varieties). The values were computed for diverse farm size groups for the mean values of all other regression variables. The results show that when farmer participation takes a positive value, the probability of seed access increases from $79 \%$ when per capita farm size is 0.25 acre to about $84.5 \%$ when farm size is 1 acre. The respective values, however, decline to $58 \%$ and $66 \%$ when participation has a zero

Table 5

Effect of farmer participation and farm size on constrained adoption of improved pigeonpea varieties

\begin{tabular}{|c|c|c|c|c|c|c|}
\hline \multirow{2}{*}{$\begin{array}{l}\text { Participation in PVS or } \\
\text { joint decision making* }\end{array}$} & \multirow{2}{*}{$\begin{array}{l}\text { Farm size } \\
\text { (acres per capita) }\end{array}$} & \multicolumn{3}{|l|}{ Probability of } & \multirow{2}{*}{$\begin{array}{l}\text { Intensity } \\
\text { of adoption }\end{array}$} & \multirow{2}{*}{$\begin{array}{l}\text { Adoption } \\
\text { rate }\end{array}$} \\
\hline & & Seed access & Positive demand & Adoption & & \\
\hline \multirow{4}{*}{ Yes } & 0.25 & 0.794 & 0.715 & 0.568 & 10,844 & 0.655 \\
\hline & 0.50 & 0.813 & 0.771 & 0.627 & 1.920 & 0.682 \\
\hline & 0.75 & 0.830 & 0.820 & 0.681 & 2.000 & 0.711 \\
\hline & 1.00 & 0.847 & 0.862 & 0.730 & 2.080 & 0.739 \\
\hline \multirow[t]{4}{*}{ No } & 0.25 & 0.582 & 0.486 & 0.283 & 1.607 & 0.571 \\
\hline & 0.50 & 0.608 & 0.556 & 0.338 & 1.671 & 0.594 \\
\hline & 0.75 & 0.634 & 0.623 & 0.395 & 1.738 & 0.618 \\
\hline & 1.00 & 0.659 & 0.686 & 0.452 & 1.809 & 0.643 \\
\hline
\end{tabular}

${ }^{*}$ Participation in variety selection (PVS) affects seed access while participation of women in variety choice and planting decisions affects the desired demand for new varieties. 
value. This shows the extent of effects one can expect if farmers participated in variety choice through on-farm trials and demonstrations, other factors kept constant. A similar effect is observed on the probability of desired positive demand for new varieties. Under participatory decision-making, the probability of positive demand for new varieties increases from $71 \%$ when farm size is 0.25 acre to $86 \%$ when farm size is 1 acre per capita. Under the constrained adoption process, the probability of actual variety adoption is the product of the probability of positive desired demand in the first stage and the probability of seed access. When participation is ensured, this probability ranges from about $57 \%$ at the lowest per capita farm size of 0.25 acre to $73 \%$ when farm size is 1 acre. However, the comparative probabilities decline to $28 \%$ and $45 \%$ when farmer participation is not ensured. This demonstrates the important roles that farmer participation in variety selection and women's participation in variety choice and planting decisions will have under constrained technology adoption process. The intensity of adoption measured as total area under improved varietiespredicted values of $\mathrm{E}[\mathrm{Y} \mid \mathrm{X}, \mathrm{Y}>0]$ — and the adoption ratio- the proportion of pigeonpea area allocated to improved varieties under the alternative scenarios are also shown in the table. The results indicate that for the average farm size of about 0.5 acre per capita the ratio of partial adoption increases from $59 \%$ when farmer participation is not ensured to about $68 \%$ when farmers actively participate in variety selection and technology choice decisions. Accordingly, the intensity adoption for an average farm size increases from 1.67 to 1.92 acres.

The disaggregated effect of geographical targeting along with the above variables computed around the mean farm size of about 0.5 acre per capita is shown in Table 6. Because of the different levels of effort in variety promotion and development of local seed systems, the probability of accessing improved seeds, desired positive demand, and the probability of adoption vary significantly within the three zones included in this study. Under the constrained adoption process, the probability of seed access, positive demand, and adoption are highest in the Singe ward, which has the highest values for targeted extension effort (proxied through the average level of farmer awareness of improved varieties), and development of local seed systems (proxied through farmer experience in FTF and amount of saved seed received from the first source). This ward also has the highest average level of working capital per farmer, which seems to have facilitated technology uptake as is demonstrated by the total area of land allocated to improved varieties in 2003-2004. ${ }^{6}$ In Singe, the average area planted to improved varieties was 1.48 acres compared to 0.76 acre in Bonga and 0.4 acre in Babati wards. The results also show that the probability of adoption is lowest in Babati ward even when farmer participation is ensured, indicating the lower overall extension and

\footnotetext{
${ }^{6}$ For example, about $50 \%$ of farmers in Singe had experience in FTF technology exchange, which compares to $37.5 \%$ for Bonga and $30 \%$ for Babati. Similarly, a given farmer knows at least 1.3 new varieties, while the values for Bonga and Babati are 1.2 and 0.9. Women farmers also seem to be more active in decision making in Singe (39\%) than the other wards (36\% for Bonga and $32 \%$ for Babati).
}

seed delivery effort in this zone. For the average household, the probability of adoption in the lowest adopting village ranges from $10 \%$ in the absence of participation to $30 \%$ when farmer participation is possible. The comparative values for Singe ward are $65 \%$ to $86 \%$, indicating how proper targeting and extension efforts to improve local seed systems and farmer awareness of new varieties can improve the likelihood of variety uptake and the intensity of adoption.

\subsection{Economic impact of improved seed access}

The DREAM model results for the wider economic returns to investments in developing the new varieties in Tanzania are given in Table 7. The results show that under the average yield gain of $67 \%$, such investments would generate significant social benefits to smallholder farmers and consumers in Babati, and through spillovers, to the rest of Tanzania. In fact, these investments would have generated sufficient social net benefits even without accounting for the spillovers. The smallholder farmers benefit most from the new varieties through increased productivity and lower average costs of production. The government also benefits from increased tax revenues received from producers and consumers. The total economic surplus in terms of net present values (NPV) amounts to over US\$6.1 million, with an internal rate of return of $32.2 \%$. These benefits are likely to generate significant impacts on food, nutrition, and poverty. This is particularly important as pigeonpeas serve as a vital source of protein for poor families and provide cash for marginal farmers in drier areas. During the 2003 season, the average marketed surplus of adopting farmers was about $716 \mathrm{~kg} / \mathrm{year}$, while those growing local varieties sold only $349 \mathrm{~kg}$ of pigeonpeas. This crop accounted for about $50 \%$ of the cash incomes of the sample farmers during the year, showing the key role of this crop as source of cash for the smallholder farmers in the area. Adoption of new varieties may also generate other nonquantified benefits (e.g., fuelwood, fodder, etc.), showing that our impact estimates are likely to be underestimated.

In order to assess the robustness of the estimated benefits, a sensitivity analysis was undertaken with respect to certain key parameter values, including demand and supply elasticities, spillover coefficients, and the estimated yield again from adoption of disease resistant varieties. The results are not sensitive to demand elasticity but quite sensitive to supply elasticity, yield gain, and spillover coefficient (Table 8). The sensitivity to the latter three parameters is mainly due to their direct influence on applied supply shifts in the model. This follows from the Alston, Norton, and Pardey (ANP) method for calculating supply shifts in estimating the economic surplus (Oehmke and Crawford, 2002), which the DREAM model is also using. ${ }^{7}$ The demand elasticities were changed by $\pm 50 \%$, but the resulting

\footnotetext{
${ }^{7}$ Despite the sensitivity of the ANP approach to the value of supply elasticity, Oehmke and Crawford (2002) discuss several conceptual and practical advantages from using this approach for estimating the impacts of research investments.
} 
Table 6

Effect of targeting and farmer participation on the two-stage constrained adoption of improved pigeonpea varieties

\begin{tabular}{|c|c|c|c|c|c|c|}
\hline \multirow{2}{*}{$\begin{array}{l}\text { Target } \\
\text { zone (ward) }\end{array}$} & \multirow{2}{*}{$\begin{array}{l}\text { Participation in PVS or } \\
\text { joint decision making* }\end{array}$} & \multicolumn{3}{|l|}{ Probability of } & \multirow{2}{*}{$\begin{array}{l}\text { Intensity of } \\
\text { adoption }\end{array}$} & \multirow{2}{*}{$\begin{array}{l}\text { Adoption } \\
\text { ratio }\end{array}$} \\
\hline & & Seed access & Positive demand & Adoption & & \\
\hline \multirow[t]{2}{*}{ Single } & Yes & 0.975 & 0.879 & 0.857 & 2.125 & 0.781 \\
\hline & No & 0.912 & 0.715 & 0.652 & 1.844 & 0.678 \\
\hline \multirow[t]{2}{*}{ Bonga } & Yes & 0.767 & 0.769 & 0.590 & 1.918 & 0.621 \\
\hline & No & 0.545 & 0.553 & 0.302 & 1.669 & 0.540 \\
\hline \multirow[t]{2}{*}{ Babati } & Yes & 0.490 & 0.626 & 0.306 & 1.742 & 0.662 \\
\hline & No & 0.261 & 0.389 & 0.102 & 1.521 & 0.578 \\
\hline
\end{tabular}

*As in Table 5 .

Table 7

Impact of pigeonpea research in Tanzania-returns to R\&D investments

\begin{tabular}{|c|c|c|c|c|c|c|c|}
\hline \multirow[t]{2}{*}{ Region } & \multicolumn{4}{|c|}{ Present value of R\&D benefits (US $\$ 1,000)^{*}$} & \multirow{2}{*}{$\begin{array}{l}\text { R\&D and extension } \\
\text { cost (US\$ } 1,000)^{*}\end{array}$} & \multirow{2}{*}{$\begin{array}{l}\text { Present value } \\
\text { of net benefits* }\end{array}$} & \multirow[t]{2}{*}{$\operatorname{IRR}(\%)$} \\
\hline & Producers & Consumers & Government & Total & & & \\
\hline Babati & 4,605 & 3 & 21 & 4,628 & 184 & 4,444 & 35.40 \\
\hline Rest of Tanzania & 2,041 & 26 & 10 & 2,077 & 388 & 1,689 & 22.44 \\
\hline Aggregate Tanzania & 6,646 & 29 & 31 & 6,705 & 572 & 6,133 & 32.2 \\
\hline
\end{tabular}

*Computed using a real social rate of discount of $5 \%$.

Table 8

Sensitively analyses of returns to R\&D investments

\begin{tabular}{|c|c|c|c|c|c|c|c|c|}
\hline \multirow[t]{2}{*}{ Parameters } & \multirow[t]{2}{*}{ Base run value } & \multirow[t]{2}{*}{ New values } & \multirow[t]{2}{*}{ Relative change (\%) } & \multicolumn{4}{|c|}{ Benefit change relative to base run } & \multirow[t]{2}{*}{ IRR change (\%) } \\
\hline & & & & Producer $(\%)$ & Consumer $(\%)$ & Government $(\%)$ & Total $(\%)$ & \\
\hline \multirow[t]{2}{*}{ Demand elasticity } & \multirow[t]{2}{*}{0.6} & 0.3 & -50 & -0.48 & 23.00 & -0.33 & -0.38 & -0.60 \\
\hline & & 0.9 & +50 & 0.33 & -15.33 & 0.33 & 0.26 & 0.45 \\
\hline \multirow[t]{2}{*}{ Supply elasticity } & \multirow[t]{2}{*}{1} & 0.8 & -20 & 25.24 & 14.63 & 0.65 & 25.08 & 8.30 \\
\hline & & 1.2 & +20 & -16.80 & -11.15 & 0.00 & -16.70 & -6.80 \\
\hline \multirow[t]{2}{*}{ Yield gain } & \multirow[t]{2}{*}{$67 \%$} & $56 \%$ & -20 & -17.57 & -16.38 & -16.34 & -17.56 & -7.14 \\
\hline & & $80 \%$ & +20 & 21.34 & 19.86 & 19.61 & 21.33 & 7.5 \\
\hline \multirow[t]{2}{*}{ Spillover coefficient } & \multirow[t]{2}{*}{0.5} & 0.25 & -50 & -15.89 & -16.03 & -16.01 & -15.90 & -3.10 \\
\hline & & 0.75 & +50 & 16.58 & 16.72 & 16.67 & 16.58 & 2.79 \\
\hline
\end{tabular}

effects on the estimated benefits are less than $0.5 \%$. However, a $\pm 20 \%$ change in the supply elasticity changes the estimated benefits between $-16 \%$ and $+25 \%$, showing higher sensitivity for this parameter. However, the aggregate supply elasticity for pigeonpea is unlikely to be more than $1 \%$ as farmers often face market access, credit, and land constraints that stifle the capacity to expand production. Changes in the estimated yield gain from adoption of new varieties will also have significant effects on estimated economic benefits. For a $\pm 20 \%$ change in the average estimated yield gain, the total benefits change by $-17 \%$ and $+21 \%$. In relation to the spillover coefficient, a $50 \%$ change in the estimated spillover potential seems to affect the aggregate benefits by $-15 \%$ to $+16 \%$. There is no technical reason limiting the realization of the gains from Babati to other similar pigeonpea growing areas of the country. The upper value of 0.75 may in fact be more plausible than the lower value of 0.25 . However, the investments in developing the new farmer and market preferred and disease resistant varieties remain attractive even under the lower and conservative estimates for supply elasticity, yield gains, and spillover coefficients.

In addition to the sensitivity analysis of the base model parameters, we explore the lost economic benefits from not providing improved access to seed and the potential gains from alternative policies addressing the seed access constraint. Given the pivotal role of the seed access constraint in determining adoption of FRIP varieties, it is important to analyze the payoffs from alternative policy approaches to address this constraint. As clearly shown in Table 5, better seed access considerably improves the probability of adoption. Better seed accessibility also contributes to shorten the adoption lag-the number of years needed for the adoption rate to reach the maximum. In order to evaluate the effect of alternative seed policies, we link the results from econometric analysis to the economic surplus model simulated using the DREAM model by running additional scenarios with different levels of seed access and 
Table 9

Impact of improved seed access on economic surplus of pigeonpea adoption Tanzania

\begin{tabular}{|c|c|c|c|c|c|}
\hline \multirow[t]{2}{*}{ Scenarios } & \multirow[t]{2}{*}{ Region } & \multicolumn{4}{|c|}{ Change of R\&D benefits (\%) } \\
\hline & & Producers & Consumers & Government & Total \\
\hline \multirow[t]{2}{*}{ Improved seed access } & Babati & 18.21 & 11.11 & 15.58 & 18.20 \\
\hline & Tanzania & 12.51 & 9.96 & 9.74 & 12.49 \\
\hline \multirow[t]{2}{*}{ Improved seed access and shorter adoption lag } & Babati & 25.93 & 15.56 & 23.05 & 25.92 \\
\hline & Tanzania & 17.83 & 14.50 & 14.40 & 17.80 \\
\hline \multirow[t]{2}{*}{ Perfect seed access and shorter adoption lag } & Babati & 45.19 & 24.44 & 38.96 & 45.15 \\
\hline & Tanzania & 31.1 & 24.2 & 24.1 & 31.0 \\
\hline
\end{tabular}

compare them with the baseline results shown in Table 7. The following three seed access scenarios were simulated: ${ }^{8}$ (a) improved seed access - the probability of seed access is 0.813 and the adoption rate is 0.682 ; (b) similar to scenario above but in addition the adoption lag decreases from 7 years (the baseline) to 4 years; (c) perfect seed access and shorter adoption lag (4 years). Assuming 100\% seed accessibility, the adoption rate is 0.77 (calculated from the adoption model but not shown in Table 5). The results showing the gains from improved seed access in terms of relative changes in benefits to producers, consumers in Babati district, and whole of Tanzania are given in Table 9. Improved seed access alone would increase producer benefits in Babati district and in Tanzania by about $18 \%$ and $13 \%$, respectively. The combined effect of improved seed access and shorter adoption lag could increase producer benefits by almost $26 \%$ in Babati district and $18 \%$ in Tanzania. For the perfect seed access scenario, the gains are even larger, $45 \%$ for Babati and $31 \%$ for Tanzania. The smaller relative gain in Tanzanian compared to Babati district is due to nonperfect technology spillover effects from Babati to the rest of Tanzania. The gains from improved seed access also benefit consumers and the government. Compared to the status quo, the overall gain from improved seed policies for Tanzania would range from about $13 \%$ to $31 \%$. The total economic surplus gain is similar to the increase in the producer surplus indicating that the smallholder producers will be the major beneficiaries from increased access to improved pigeonpea varieties.

\section{Summary and conclusions}

This study analyzed the adoption determinants and estimated the overall economic benefits associated with the development of disease resistant varieties of pigeonpeas, a pro-poor and drought tolerant legume crop widely grown in many semiarid areas of Africa and Asia. The data from northern Tanzania have shown that several households are constrained from adopting new varieties due to seed access constraints that prevent some potentially adopting farmers from growing new varieties. Unlike many adoption studies that disregard such adoption thresholds, we exploit this information to estimate more

\footnotetext{
${ }^{8}$ These scenarios are related to the improved seed access probabilities and adoption rates for the average farm size in survey district $(0.5$ ha/per capita) shown in Table 5.
}

efficient versions of the $\mathrm{DH}$ model to analyze the determinants of the probability and intensity of variety adoption conditional on overcoming these thresholds. The study provides new insights on the role of supply side constraints that limit variety adoption despite positive demand for new cultivars. The overall economic gains from variety development and the benefits from tackling these constraints were analyzed further using the economic surplus approach.

The results show that the new pigeonpea varieties improve household incomes by up to $80 \%$ as disease-induced yield losses decrease from about $50 \%$ for local varieties to just about $5 \%$ for the new varieties. The study finds that despite these high benefits, many farmers in the growing areas did not adopt the disease-resistant varieties mainly due to inadequate local supply of seed and agronomic information about the new cultivars. As seed requirements for pigeonpea were small and many farmers could afford to buy small quantities, farmers indicated that effective demand or credit was not a major limiting factor in making planting decisions for new varieties. The econometric results confirmed that the spread and intensity of technology uptake is constrained by seed access. Participation in informal seed networks, in on-farm variety selection, and ownership of household transport assets increase the likelihood that farmers will access improved seeds. The overall observed demand for improved varieties was positively determined by the participation of women in variety choice and planting decisions, family education, availability of working capital, level of awareness about the new technologies, and nonstochastic wealth factors and productive assets (land and livestock).

These results show that while farmer-to-farmer transfer of new seeds plays an important role in improving access to new seeds, it will not be sufficient to spread the varieties widely and more quickly as many farmers with positive desired demand had no or limited access to quality seeds of improved varieties. What are the key policy implications from these results? There is an urgent need to strengthen and leverage rural institutions to remedy pervasive market failures in both seed and output markets in semi-arid areas with limited market infrastructure, ${ }^{9}$

\footnotetext{
${ }^{9}$ Following Dorward et al. (2005), the term "institutions" is used in the broad sense to encompass rules, enforcement mechanisms, and organizational arrangements that promote production, formal and informal exchange and transactions in both seed and output markets. Farmer organizations, village agrodealers, and alternative coordination mechanisms (e.g., contract farming, seed revolving funds, etc.) can be used to strengthen institutions and enhance the functioning of rural markets.
} 
and increase public efforts in promotion of new varieties to improve access to seed and stimulate demand among those lacking awareness about new varieties. The government and extension systems will need to take the lead in technology promotion and dissemination at the initial stages and in creating an enabling environment for effective participation of the private sector. The positive effect of PVS and farmer-to-farmer seed exchange in improving farmer access to new varieties suggests that these approaches can be used as effective tools in stimulating the demand for new varieties. The participation of pigeonpea farmers (especially women) in variety choice enhances the relevance and local adaptability of new technologies and shortens the time required for research to generate impacts.

Awareness campaigns for improved varieties, combined with improved local availability of improved seeds at reasonable prices offer the most promising policy mix to accelerate and expand adoption. Unlike major staples (e.g., maize), the overall size of the pigeonpea seed market is limited and may not be attractive to private agents. Once access is ensured, farmers can also save pigeonpea seed and recycle it over three to four years without significant loss in productivity. But participation of farmer organizations and the private sector can be expanded through better promotion and innovative seed production, distribution, and marketing strategies. This may include revolving seed schemes where small initial funds provided to farmer groups or cooperatives can be used to reach more farmers while recovering the initial capital; small seed packs, which can be marketed through a wider network of local input agro-dealers; trained local seed farmers to locally produce quality declared seeds and cut down distribution costs; and use of relief and recovery programs through voucher-based systems that stimulate adoption without undermining local seed systems. This needs to be complemented by simpler variety release, registration, and quality control procedures, which help support the development of both formal and informal seed systems.

Since the derived demand for seed very much depends on the output price, better market access and better producer prices for the grain will also stimulate adoption. The initial lessons from the effective partnerships between private and public sector institutions in the process of technology and market development attest to these results. The results also demonstrate that if necessary investments are made in improving seed access and wider diffusion of new varieties, the economic benefits in Tanzania would significantly outweigh the costs even with modest yield gains assumed from variety adoption. The social gains would be higher if one accounts for nonmarket ecosystem services (e.g., soil fertility benefits) associated with adoption of legumes in cereal-based systems.

\section{Acknowledgments}

We would like to thank the Danish International Development Agency (DANIDA) and ICRISAT for their financial support to this study. The Selian Agricultural Research Institute (SARI) in Tanzania provided logistical and technical support for the study. We thank S. Silim, G. Muricho, S. Lyimo, P. Audi, J.L. Christiansen, J. Mligo, R. Jones, F. Mizambwa, and D. Maniro for their valuable comments on an earlier version of the article and two anonymous reviewers for useful comments and suggestions. The usual disclaimers apply.

\section{References}

Adesina, A.A., Zinnah, M.M., 1993. Technology characteristics, farmers' perceptions and adoption decisions: A Tobit model application in Sierra Leone. Agric. Econ. 9, 297-311.

Alston, M.J., Norton, W.G., Pardey, P.G., 1995. Science under Scarcity. Principles and Practice for Agricultural Research Evaluation and Priority Setting. Cornell University Press, Ithaca and London.

Baker, J.L., 2000. Evaluating the Impacts of Development Projects on Poverty. A Handbook for Practitioners. The World Bank, Washington, DC.

Coady, D.P., 1995. An empirical analysis of fertilizer use in Pakistan. Economica 62, 213-234.

Cragg, J.G., 1971. Some statistical models for limited dependent variables with applications to the demand for durable goods. Econometrica 39, 829-844.

Cromwell, E., 1996. Government, Farmers and Seeds in a Changing Africa. CAB International, Wallingford, UK, pp. 174.

Croppenstedt, A., Demeke, M., Meschi, M.M., 2003. Technology adoption in the presence of constraints: The case of fertilizer demand in Ethiopia. Rev. Dev. Econ. 7(1), 58-70.

de Janvry, A., Fafchamps, M., Sadoulet, E., 1991. Peasant household behavior with missing markets: Some paradoxes explained. Econ. J. 101, 14001417.

Dorward, A., Kydd, J., Morrison, J., Poulton, C., 2005. Institutions, markets and economic development: Linking development policy to theory and praxis. Development and Change 361, 1-25.

Gwata, E., Silim, S.N., Mgonja, M., 2006. Impact of new sources of resistance to fusarium wilt in pigeonpea. Phytopathology 154, 62-64.

Holden, S.T., Shiferaw, B. Pender, J., 2001. Market imperfections and land productivity in the Ethiopian highland. J. Agric. Econ. 52(3), 53-70.

Jones A.M., 1992. A note on the computation of the double hurdle model with dependence with an application to tobacco expenditure. Bull. Econ. Res. 44(1), 67-74.

Joshi, P.K., Parthasaraty Rao, P., Gowda, C.L.L., Jones, R.B., Silim, S.N., Saxena, K.B., Kumar, J., 2001. The World Chickpea and Pigeonpea Economies: Facts, Trends, and Outlook. ICRISAT, Patancheru, India.

Kaliba, A.R.M., Verkuijl, H., Mwangi, W., 2000. Factors affecting adoption of improved maize seeds and use of inorganic fertilizer for maize production in the intermediate and lowland zones of Tanzania. J. Ag. \& Appl. Econ. 32(1), 35-47.

Kimhi, A., 1999. Double-hurdle and purchase infrequency demand analysis: A feasible integrated approach. Euro. Rev. Agric. Econ. 26(4), 425-442.

Kristjanson, P., Okike, I., Tarawali, S., Singh, B.B., Manyong, V.M., 2005. Farmers' perceptions of benefits and factors affecting the adoption of improved dual-purpose cowpea in the dry savannas of Nigeria. Agric. Econ. $32,195-210$.

Lo Monaco, G., 2003. The Competitiveness of African Pigeon Pea Exports in International Markets. Socioeconomics and Policy Working Paper No. 15. ICRISAT, Patancheru, India.

Lyimo, S., Personal communication, 2008. Selian Agricultural Research Institute, Arusha, Tanzania.

Maddala, G. S., 1983. Limited Dependent and Qualitative Variables in Econometrics. Cambridge University Press, London.

Maredia, M., Byerlee, D., Pee, P., 1998. Impacts of food crop improvement research in Africa. SPAAR Occasional Paper Series No.1, World Bank, Washington, DC. Available at: http://www.worldbank.org/afr/aftsr/impaper.pdf (accessed on March 11, 2008). 
Matshe, I., Young, T., 2004. Off-farm labour allocation decisions in small-scale rural households in Zimbabwe. Agric. Econ. 30(3), 175-186.

Moffatt, P.G., 2005. Hurdle models of loan default. J. Oper. Res. Soc. 56, 1063-1071.

Morris, M., 1998. Maize Seed Industries in Developing Countries. Lynne Rienner Publishers, Boulder, Colorado.

Moyo, S., Norton, W.G., Alwang, J., Rhinehart, I., Deom, C.M., 2007. Peanut research and poverty impacts of variety improvement to control peanut viruses in Uganda. Am. J. Agric. Econ. 89(2), 448-460.

Nkonya, E.M., Schroeder, T., Norman, D., 1997. Factors affecting adoption of improved maize seed and fertilizer in northern Tanzania. J. Ag. Econ. 48(1), $1-12$.

Nweke, F., Spencer, D., Lyman, J., 2000. The cassava transformation: Africa's best kept secret. Michigan State University Press, East Lansing, MI.

Oehmke, J.F., Crawford, E.W., 2002. The sensitivity of returns to research calculations to supply elasticity. Am. J. Agric. Econ. 84(2), 366-369.

Pender, J., Kerr, J.M., 1998. Determinants of farmers' indigenous soil and water conservation investments in semi-arid India. Agric. Econ. (19), 113-125.

Pingali, P.L., Rosegrant, M.W., 2001. Intensive food systems in Asia: Can the degradation problem be reversed? In: Lee, D.R., Barrett, C.B., (Eds.), Tradeoffs or Synergies: Agricultural Intensification, Economic Development and the Environment. CABI Publishing, Wallingford, UK, pp. 383-397.

Rohrbach, D., Tripp, R., 2001. Policies for African seed enterprise development. Food Policy 26(2), 147-161.

Shiferaw, B., Freeman, H.A., Navrud, S., 2004. Valuation methods and methodologies for assessing NRM technology impacts. In: B. Shiferaw, H.A.
Freeman, S. Swinton (Eds.), Natural Resource Management in Agriculture: Methods for Assessing Economic and Environmental Impacts. CABI Publishing, Wallingford, pp. 19-51.

Shiyani, R.L., Joshi, P.K., Asokan, M., Bantilan, M.C.S., 2002. Adoption of improved chickpea varieties: KRIBHCO experience in tribal region of Gujarat, India. Agric. Econ. 27(1), 33-39.

Singh, I., Squire, L., Strauss, J. (Eds.), 1986. Agricultural Household Models. Extension, Application and Policy. The Johns Hopkins University Press, New York.

Smith, M.D., 2003. On dependency in double-hurdle models. Statistical Papers 44(4), 581-595.

Tobin, J., 1958. Estimation of relationships for limited dependent variables. Econometrica 26, 24-36.

Tripp, R., 2000. Strategies for seed systems development in sub-Saharan Africa: A study of Kenya, Malawi, Zambia and Zimbabwe. SocioEconomics and Policy Working Paper No. 2, International Crops Research Institute for the Semi-Arid Tropics (ICRISAT), Patancheru, India, pp. 56.

Vuong, Q., 1989. Likelihood ratio tests for model selection and non-nested hypotheses. Econometrica 57, 307-334.

Woldehanna, T., Lansink, A.O., Peerlings, J., 2000. Off-farm work decisions on Dutch cash crop farms and the 1992 and Agenda 2000 CAP reforms. Agric. Econ. 22, 163-171.

Wood, S., You, L., Baitx, W., 2001. Dynamic Research Evaluation for Management (DREAM). Version 3. User Manual. International Food Policy Research Institute, Washington, DC. 